University of Nebraska - Lincoln

DigitalCommons@University of Nebraska - Lincoln

\title{
Mechanical Barrier for Preventing Climbing by Lesser Mealworm (Coleoptera: Tenebrionidae) and Hide Beetle (Coleoptera: Dermestidae) Larvae in Poultry Houses
}

Christopher Geden

USDA-ARS, Chris.geden@ars.usda.gov

David Carlson

USDA-ARS

Follow this and additional works at: https://digitalcommons.unl.edu/usdaarsfacpub

Part of the Agricultural Science Commons

Geden, Christopher and Carlson, David, "Mechanical Barrier for Preventing Climbing by Lesser Mealworm (Coleoptera: Tenebrionidae) and Hide Beetle (Coleoptera: Dermestidae) Larvae in Poultry Houses" (2001). Publications from USDA-ARS / UNL Faculty. 979.

https://digitalcommons.unl.edu/usdaarsfacpub/979

This Article is brought to you for free and open access by the U.S. Department of Agriculture: Agricultural Research Service, Lincoln, Nebraska at DigitalCommons@University of Nebraska - Lincoln. It has been accepted for inclusion in Publications from USDA-ARS / UNL Faculty by an authorized administrator of DigitalCommons@University of Nebraska - Lincoln. 


\title{
Mechanical Barrier for Preventing Climbing by Lesser Mealworm (Coleoptera: Tenebrionidae) and Hide Beetle (Coleoptera: Dermestidae) Larvae in Poultry Houses
}

\author{
CHRISTOPHER J. GEDEN AND DAVID A. CARLSON \\ Center for Medical, Agricultural and Veterinary Entomology, USDA-ARS, P. O. Box 14565, Gainesville, FL 32604
}

J. Econ. Entomol. 94(6): 1610-1616 (2001)

\begin{abstract}
Mechanical barriers consisting of bands of polyethylene terepthalate resin attached to wooden posts by latex caulk adhesive and staples were $100 \%$ effective in preventing passage of dispersing lesser mealworm, Alphitobius diaperinus (Panzer), larvae in the laboratory. Barriers continued to be $100 \%$ effective after being held in a caged layer poultry house for 3 mo. Polyethylene terepthalate barriers installed on support posts in a pullet house in Brooker, FL, were $>92 \%$ effective against natural populations of lesser mealworm larvae 6 mo after installation. The barriers also were $>94 \%$ effective against natural populations of larvae of the hide beetle, Dermestes maculatus DeGeer, when fly populations were low. Fecal spot depositions by house flies in excess of 31 cumulative fly spots per square centimeter on spot cards reduced the effectiveness of the barriers to $79-90 \%$, and barrier efficacy was reduced to $40-56 \%$ when fly spots covered $>80 \%$ of the surface of the plastic. Washing the barriers with water to remove fly spots restored their effectiveness against hide beetle larvae to $>99 \%$.
\end{abstract}

KEY WORDS Litter beetles, mechanical barrier, lesser mealworm, hide beetle, Dermestes maculatus, Alphitobius diaperinus.

THE LESSER MEALWORM, Alphitobius diaperinus (Panzer), and the hide beetle, Dermestes maculatus DeGeer, are among the most common beetles in poultry manure worldwide (Turner 1986, Geden et al. 1999). A. diaperinus is a reservoir of numerous avian pathogens, including Salmonella typhimurium, Escherichia coli, tapeworms, enteric viruses, and avian leukosis virus (Avancini and Ueta; 1990, Axtell and Arends 1990; Despins et al. 1994; McAllister et al. 1994, 1996). Little is known of the reservoir competence of the hide beetle.

In caged-layer poultry houses, the beetles consume spilled feed, dead birds, feces, and other organic materials. Hide beetles prefer materials with a high protein content (Cloud and Collison 1986), and often congregate around cracked eggs and the carcasses of birds and rodents. When lesser mealworm populations are high, mature larvae emigrate from the manure in search of isolated pupation sites, often resulting in extensive damage to thermal insulation materials in the facility (Ichinose et al. 1980, Geden and Axtell 1987). Dermestes larvae tunnel into wood as well as insulation materials to form their pupal cells, and the damage to building support posts and joists can be severe (Cloud and Collison 1985; Stafford et al. 1988). Annual losses to these insects have been estimated at $\$ 16$ and \$10 million in Virginia and Georgia, respectively (Turner 1986, Riley et al. 1997).

Control of lesser mealworm and hide beetle populations is difficult in modern high-rise layer houses, where manure accumulation times often exceed $1 \mathrm{yr}$.
Although the beetles are susceptible to many insecticides applied as premise treatments (Vaughan et al. 1984, Cloud and Collison 1985, Geden et al. 1987b), the effectiveness of such treatments in the field is limited by the rapid accumulation of dust on the treated surfaces (Despins et al. 1991). Several natural enemies of lesser mealworm have been found, including protozans, fungi, and a parasitic mite (Steinkraus et al. 1991, 1992; Steinkraus and Cross 1993), and steinernematid nematodes have been tested in the field (Geden et al. 1987a). Although some of these biological control agents look promising, none have been documented as providing satisfactory control of beetle populations.

An alternative to managing beetle populations is to disrupt their movement so that emigrating larvae are denied access to vulnerable building structures. This denial of access could be accomplished by the application of bands of toxicants or pathogens to support posts and walls that would kill larvae before they can cause damage (Geden et al. 1998). Another approach is the use of mechanical barriers to prevent the passage of beetles as they attempt to emigrate from the manure. Laboratory observations indicated that larvae of both beetle species were unable to climb a variety of plastic surfaces, including sheets of polyethylene terepthalate. Polyethylene terepthalate is commercially available, inexpensive, durable, and can be formed into various shapes by using heat. The objective of the current study was to evaluate the effec- 


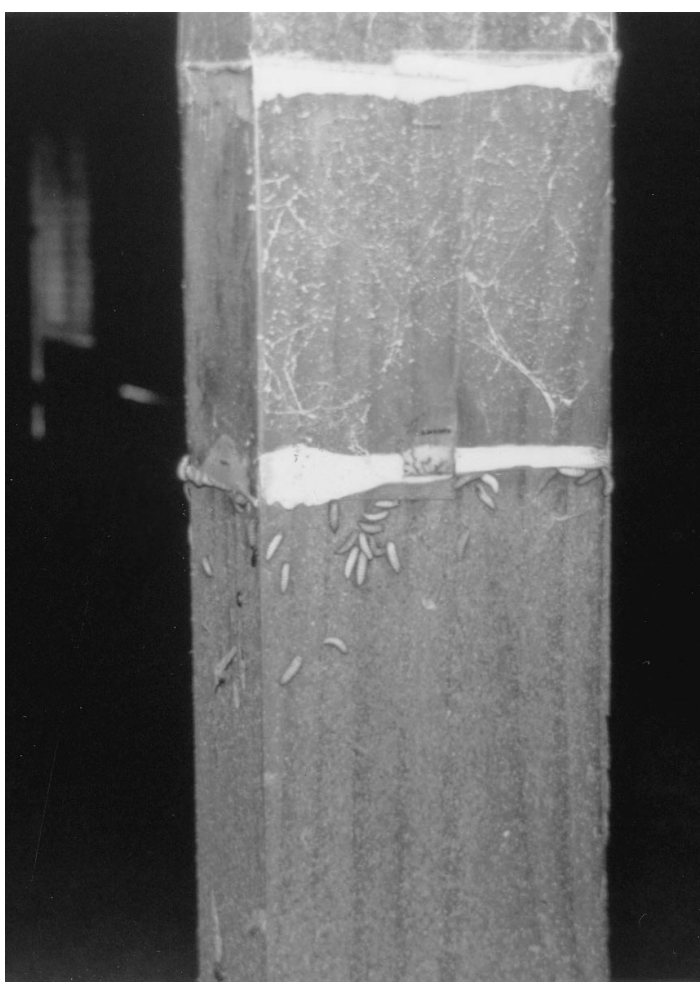

Fig. 1. Polyethylene terepthalate plastic collar attached to post, with hide beetle larvae congregating near the base of the barrier.

tiveness of plastic barriers for preventing passage of emigrating beetle larvae in the field.

\section{Materials and Methods}

Preliminary Laboratory Bioassays. Polyethylene terepthalate type $\mathrm{G}$ was obtained from AIN Plastics County (Tampa, FL) in rolls that were $\approx 30 \mathrm{~m}$ in length, $15.2 \mathrm{~cm}$ in width, and $0.51 \mathrm{~mm}$ in thickness. In preliminary laboratory tests, the plastic was cut into lengths of $27 \mathrm{~cm}$ and folded around conventional construction-grade pine boards with side dimensions of 8.7 by $3.7 \mathrm{~cm}$, cut into lengths of $45.5 \mathrm{~cm}$. A $1 \mathrm{~cm}$ wide band of latex caulk was first applied to the wood $13 \mathrm{~cm}$ from the bottom of the board. The plastic was then bent around the board with the lower edge positioned $12 \mathrm{~cm}$ from the bottom of the board and pressed against the wood so that the caulk provided a seal along the bottom edge of the plastic. The plastic was held in place by two staples fastened along the $2.5-\mathrm{cm}$ seam where the ends of the plastic overlapped. Treated boards were placed, paired with an untreated control board, into 40 by 20 -cm plastic pans with $\approx 350$ mature lesser mealworm larvae ( $n=6$ pairs of boards). The mature larvae, collected from a poultry house near Brooksville, FL, were separated from younger larvae before the test by the use of a No. 14 U.S. Standard testing sieve (Newark Wire Cloth Company, Newark, NJ) with 1.5-mm openings as described by

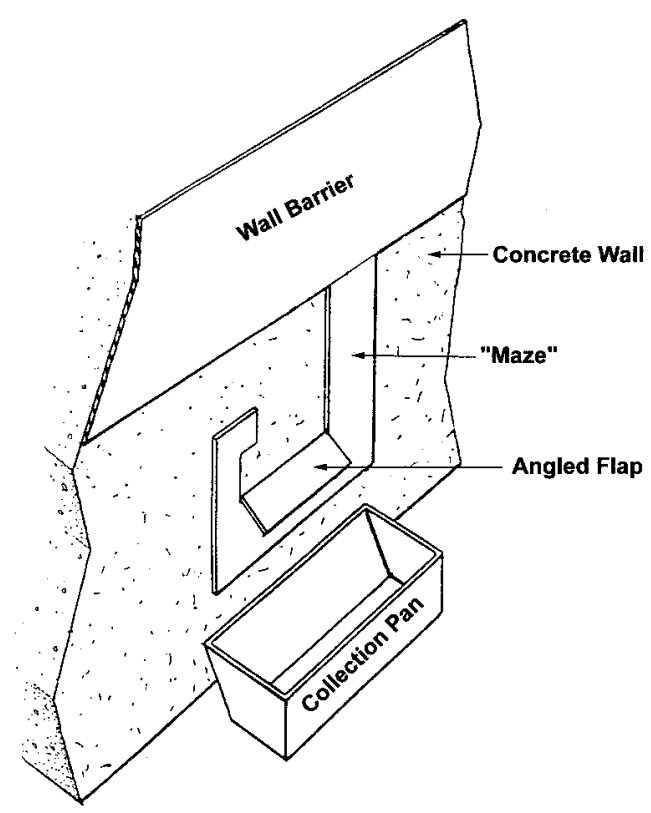

Fig. 2. "Maze" collecting device attached to a horizontal section of wall barrier. Larvae moving along the lower edge of the horizontal barrier follow the margin of the plastic into the center of the device and drop down an angled flap into a collecting pan.

Steinkraus et al. (1991). Larvae climbing the boards were monitored by wrapping $10 \mathrm{~cm}$ wide corrugated cardboard around the top end of each board, with the cardboard held in place by two rubber bands. The cardboard traps were removed from the boards after $24 \mathrm{~h}$ and the number of larvae counted.

In a second laboratory study, boards with barriers were prepared as described above except that half of the plastic barriers were treated with a surface film of Teflon. Boards were then taken to a commercial caged-layer house near Brooksville, FL, and suspended from ceiling joists to allow natural poultry house dust to accumulate on the plastic barriers. This facility had high beetle populations at the time but few flies, so that the deposits on the boards consisted of dust with a minimum of fly specking. After 3 mo of exposure the boards were returned to the laboratory, placed in pans containing 350 larvae, and larval climbing was assessed by cardboard traps as described previously.

Field Tests with Lesser Mealworm. Field tests were conducted in a commercial high-rise pullet house near Brooker, FL. This facility has three rows of 34 posts on the ground level supporting four rows of cages housing $\approx 100,000$ birds during 18 -wk growth cycles, with 2 - to 6 -wk intervals between flocks for bird removal, manure cleanout, and maintenance. The posts, made of pressure-treated pine, measured $\approx 8.8$ by $13.7 \mathrm{~cm}$, and were set in concrete footers that formed a low wall (41 $\mathrm{cm}$ in height by $19 \mathrm{~cm}$ in width) along each row of posts. 
Table 1. Laboratory bioassays of a polyethylene terepthalate plastic and caulk barrier to prevent climbing of lesser mealworm larvae

\begin{tabular}{|c|c|c|}
\hline \multirow[t]{2}{*}{ Treatment } & \multicolumn{2}{|c|}{$\begin{array}{c}\text { Mean } \pm \text { SE no. } \\
\text { lesser mealworm larvae } \\
\text { collected after } 24 \mathrm{~h} \\
\text { in cardboard traps on boards }\end{array}$} \\
\hline & With barrier & Without barrier \\
\hline $\begin{array}{l}\text { Boards held indoors } \\
\text { Boards placed in a poultry house } \\
\quad \text { for } 3 \text { mo }\end{array}$ & $0.0 \pm 0.0$ & $201.5 \pm 4.5$ \\
\hline Barrier alone & $0.0 \pm 0.0$ & $140.0 \pm 37.6$ \\
\hline Barrier plus teflon & $0.0 \pm 0.0$ & $159.3 \pm 42.7$ \\
\hline
\end{tabular}

Boards with and without barriers placed in pans with 350 mature larvae. $n=6$ pairs (treated and untreated) of boards per treatment.

Barriers were prepared by first cutting the plastic described previously into $30 \mathrm{~cm}$ lengths. The sections were then folded into two $90^{\circ}$ folds by using a heated mandrel so that the middle section would attach to the short side of the post and the two side-pieces of the plastic would each reach past the midpoint of the long side of the post. In this way, two opposing sections of the barrier were placed on opposite sides of each post and joined along the two regions of overlap by staples to form a complete collar. Beads of latex caulk (Polyseamseal All Purpose Adhesive Caulk, Darworth County, Mentor, $\mathrm{OH}$ ) were applied to the post near the upper and lower margins of the barrier before pressing the plastic into position and fastening it with staples (Fig. 1).

Barriers were applied to all 102 posts in the facility in November 1997, during the interval between flocks and left undisturbed until June 1998, when large numbers of lesser mealworms were observed in the manure. Emigrating beetles were monitored by stapling $76 \mathrm{~cm}$ lengths of $20 \mathrm{~cm}$ wide corrugated cardboard in a collar located either immediately above or below the barriers on each of 10 randomly selected posts on 17 June. The cardboard traps were removed after $7 \mathrm{~d}$ and the beetles counted. A second set of cardboard traps was placed on 15 July, $10 \mathrm{~d}$ before the birds were removed. Barriers were washed with water in late August, during the interval between flocks, to remove fly spots that had accumulated during the 8 mo after installation.

Field Tests with Hide Beetle Larvae and Effect of Fly Spots on Barrier Efficacy. A new flock was housed in the test site on one September 1998. Within several weeks large numbers of hide beetle larvae were observed attempting to climb the posts. Beginning on 24 September, direct visual counts were made weekly of the number of larvae observed on the barriers and within $15 \mathrm{~cm}$ above and below the barriers. Counts were made weekly on all 102 posts during 24 September-24 November. For each post per week, a barrier efficiency score was calculated as the percentage of total larvae that were observed either on or above the barriers. Fly populations during this time also were assessed by the weekly replacement of $20,7.6$ by 12.7 $\mathrm{cm}$ white spot cards attached to support posts. Fly spots on the cards were counted weekly, and the cumulative fly spots per square centimeter of the cards determined during the 10 -wk observation period.

In addition to spot card data, all 102 posts were individually scored for the severity of fly spotting on 19 and 24 November 1998. Each post was classified as belonging to one of the following five categories by visual determination of the percentage of the surface area of the plastic that was covered with fly spots: $<20$, $20-40,40-60,60-80$, and $80-100 \%$. Data on barrier efficacy on each of these two dates were then classified as a function of the severity of the fly spotting and subjected to one-way analysis of variance (ANOVA) using the general linear models procedure of the statistical analysis system (SAS Institute 1987) with the fly spotting index as the grouping variable.

To determine whether fly spot removal would restore the efficacy of the barriers, half of the barriers were washed with water on three 3 December 1998. On each of the following $2 \mathrm{wk}$, cardboard traps were placed above or below the barriers as was done previously in the June and July sampling $(n=10$ traps per week for each treatment [barriers washed or unwashed, traps placed above or below the barrier]). Direct visual counts of hide beetle larvae also were made as before on the remaining 42 posts (21 washed, 21 unwashed) on these two dates. Data from the $2 \mathrm{wk}$ of sampling were combined and subjected to one-way ANOVA (SAS Institute 1987) by using the washing treatment as the grouping variable.

Wall-Mounted Barriers. In addition to the collar barriers attached to the posts of the facility, continuous strips of the plastic barrier were attached to the upper edge of the concrete footers along the side walls of the facility. The plastic was adhered to the concrete by first applying two lines of latex caulk, $10 \mathrm{~cm}$ apart,

Table 2. Litter beetle counts (mean \pm SE) from cardboard traps placed on posts above and below polyethylene terepthalate plastic and caulk barriers in a pullet house in Brooker, FL, in 1998

\begin{tabular}{|c|c|c|c|c|c|c|}
\hline \multirow{2}{*}{ Date } & \multirow{2}{*}{ Trap position } & \multicolumn{2}{|c|}{ Lesser mealworm } & \multicolumn{2}{|c|}{ Hide beetle } & \multirow{2}{*}{ All pupae } \\
\hline & & Larvae & Adults & Larvae & Adults & \\
\hline \multirow[t]{3}{*}{17 June } & Below barrier & $123.6 \pm 11.9$ & $24.4 \pm 2.4$ & $5.1 \pm 0.7$ & $1.9 \pm 0.4$ & $47.8 \pm 5.9$ \\
\hline & Above barrier & $0.1 \pm 0.1$ & $0.1 \pm 0.1$ & $0.0 \pm 0.0$ & $0.0 \pm 0.0$ & $0.0 \pm 0.0$ \\
\hline & ANOVA $F$ & $30.9^{a}$ & $32.5^{a}$ & $21.9^{a}$ & $12.8^{a}$ & $25.2^{a}$ \\
\hline \multirow[t]{3}{*}{15 July } & Below barrier & $160.9 \pm 16.1$ & $85.8 \pm 22.3$ & $7.4 \pm 1.7$ & $3.4 \pm 1.0$ & $63.7 \pm 11.6$ \\
\hline & Above barrier & $11.8 \pm 4.2$ & $1.2 \pm 0.4$ & $0.2 \pm 0.1$ & $0.1 \pm 0.1$ & $7.0 \pm 3.0$ \\
\hline & ANOVA $F$ & $80.2^{a}$ & $14.4^{a}$ & $18.4^{a}$ & $11.8^{a}$ & $22.4^{a}$ \\
\hline
\end{tabular}

Barriers installed November 1997; birds placed 6 April 1998. $n=10$ traps/position/date.

${ }^{a} P<0.01$. 
Table 3. Visual counts of hide beetle larvae on posts $(n=102)$ in a pullet house in Brooker, FL, in 1998 after installation of polyethylene terepthalate plastic and caulk barriers

\begin{tabular}{|c|c|c|c|c|c|}
\hline \multirow{2}{*}{ Date } & \multicolumn{3}{|c|}{ Mean $\pm \mathrm{SE}$ Dermestes larvae/post } & \multirow{2}{*}{$\begin{array}{c}\text { Barrier } \\
\text { efficiency }^{a}\end{array}$} & \multirow{2}{*}{$\begin{array}{l}\text { Cumulative fly } \\
\text { spots } / \mathrm{cm}^{b}\end{array}$} \\
\hline & Above barrier & On barrier & Below barrier & & \\
\hline 24 Sep & $0.0 \pm 0.0$ & $0.5 \pm 0.1$ & $17.6 \pm 1.5$ & $94.5 \pm 1.3$ & 4.1 \\
\hline 1 Oct & $0.0 \pm 0.0$ & $0.5 \pm 0.1$ & $35.4 \pm 1.9$ & $98.4 \pm 0.4$ & 14.3 \\
\hline 8 Oct & $0.0 \pm 0.0$ & $0.5 \pm 0.1$ & $28.1 \pm 2.0$ & $97.9 \pm 0.5$ & 19.4 \\
\hline 16 Oct & $0.0 \pm 0.0$ & $0.2 \pm 0.1$ & $13.1 \pm 1.5$ & $97.3 \pm 0.9$ & 31.3 \\
\hline 23 Oct & $0.0 \pm 0.0$ & $0.4 \pm 0.1$ & $2.6 \pm 0.4$ & $87.9 \pm 2.6$ & 39.5 \\
\hline 29 Oct & $0.0 \pm 0.0$ & $0.7 \pm 0.1$ & $7.7 \pm 0.9$ & $80.5 \pm 3.5$ & 43.9 \\
\hline $5 \mathrm{Nov}$ & $0.0 \pm 0.0$ & $0.2 \pm 0.1$ & $2.2 \pm 0.3$ & $86.0 \pm 3.6$ & 48.3 \\
\hline 12 Nov & $0.0 \pm 0.0$ & $0.2 \pm 0.1$ & $2.7 \pm 0.4$ & $91.2 \pm 2.6$ & 52.7 \\
\hline 19 Nov & $0.0 \pm 0.0$ & $0.9 \pm 0.2$ & $7.9 \pm 1.0$ & $78.9 \pm 3.5$ & 56.0 \\
\hline 24 Nov & $0.0 \pm 0.0$ & $1.3 \pm 0.2$ & $10.4 \pm 1.2$ & $82.1 \pm 3.2$ & 62.6 \\
\hline
\end{tabular}

Barriers installed November 1997; birds housed 2 September 1998.

${ }^{a}$ Number of larvae observed below barrier/total larvae observed.

${ }^{b}$ Cumulative counts of 20 spot cards, changed weekly, expressed as spots per square centimeter.

near the top of the concrete. The plastic was then pressed against the caulk and held in place by masking tape for several hours to ensure that it did not slide downward before the adhesive had set. Although no beetle counts were made on the wall barriers themselves, observations during the hide beetle outbreak in the autumn of 1998 indicated that beetle larvae were moving along the lower edge of the plastic in the direction of the air movement and accumulating at the downwind end of the house. In an effort to prevent these larvae from entering the walls of the end of the facility, collecting devices were placed near the ends of the wall barriers. These collecting devices were $\mathrm{J}$-shaped pieces plastic that were joined to the wall barrier to form a simple "maze" that channeled the beetles down an angled flap into metal pans positioned below the device (Fig. 2). Collecting devices were placed along both walls, and the beetles collected in the pans were counted weekly during 16 October-24 November 1998.

\section{Results}

In preliminary laboratory bioassays, no lesser mealworm larvae were able to cross the plastic barriers and enter the cardboard traps (Table 1). Similar results were observed with barriers held in a caged layer poultry house for $3 \mathrm{mo}$, indicating that normal feed, manure, and bird dust accumulations did not compromise the effectiveness of the plastic as a beetle barrier (Table 1). Observations of the larvae during the bioassays indicated that the dust on the lower margin of the barriers was removed by the larvae during their attempts to traverse them. The addition of a Teflon dispersion to the plastic had no discernable effect on the effectiveness of the barriers.

When field-installed barriers were challenged by natural populations of litter beetles, the barriers were $>99 \%$ effective against lesser mealworm larvae and adults as determined by cardboard traps placed above or below the plastic on 17 June (Table 2 ). Hide beetle populations at the time were low, but results indicated that the barriers were $100 \%$ effective against both adults and larvae of this species. One month later, there appeared to be some loss of barrier effectiveness for lesser mealworm larvae (mean, $160.9 \pm 16.1$ and $11.8 \pm 4.2$ larvae below and above the barriers, respectively) and hide beetle larvae (mean $7.4 \pm 1.7$ and $0.2 \pm 0.1$ larvae below and above the barriers, respectively) (Table 2). Although no data were collected on fly populations during this portion of the study, house fly populations during this time were high, and the apparent decline in barrier effectiveness between the June and July sampling dates may have been due to the deposition of fly spots on the plastic.

Table 4. Efficacy of polyethylene terepthalate and caulk beetle barriers for hide beetle larvae, classified by severity of spot deposition on the barriers by house flies

\begin{tabular}{|c|c|c|c|c|}
\hline \multirow{2}{*}{$\begin{array}{l}\% \text { of barrier surface } \\
\text { covered w/fly spots }\end{array}$} & \multicolumn{2}{|c|}{19 Nov 1998} & \multicolumn{2}{|c|}{24 Nov 1998} \\
\hline & $\begin{array}{l}\text { Mean }+\mathrm{SE} \\
\% \text { efficiency }^{a}\end{array}$ & $\begin{array}{l}\text { No. } \\
\text { posts }\end{array}$ & $\begin{array}{l}\text { Mean }+ \text { SE } \\
\% \text { efficiency }\end{array}$ & $\begin{array}{l}\text { No. } \\
\text { posts }\end{array}$ \\
\hline$<20$ & $98.9 \pm 1.1$ & 5 & $100.0 \pm 0.0$ & 4 \\
\hline $20-40$ & $95.1 \pm 1.1$ & 24 & $98.2 \pm 0.8$ & 27 \\
\hline $40-60$ & $77.3 \pm 6.4$ & 21 & $76.8 \pm 5.5$ & 26 \\
\hline $60-80$ & $78.6 \pm 4.6$ & 12 & $68.3 \pm 4.3$ & 15 \\
\hline $80-100$ & $55.7 \pm 13.2$ & 9 & $40.0 \pm 9.6$ & 11 \\
\hline ANOVA $F$ & $9.6^{b}$ & & $10.9^{b}$ & \\
\hline
\end{tabular}

Fly spotting on barriers determined by visual inspection.

${ }^{a}$ Number of hide beetle larvae observed below barrier/total larvae observed.

${ }^{b} P<0.01$. 
Table 5. Effect of washing fly spots from polyethylene terepthalate and caulk barriers on their effectiveness for preventing hide beetle and lesser mealworm larvae from climbing

\begin{tabular}{|c|c|c|c|}
\hline \multirow{2}{*}{$\begin{array}{l}\text { Method and location of } \\
\text { observation }\end{array}$} & \multicolumn{2}{|c|}{ Washing treatment } & \multirow{2}{*}{$\begin{array}{l}\text { ANOVA } \\
\quad F\end{array}$} \\
\hline & Washed & $\overline{\text { Unwashed }}$ & \\
\hline \multicolumn{4}{|l|}{$\begin{array}{l}\text { Mean } \pm \text { SE visual counts } \\
\text { of hide beetle } \\
\text { larvae/post: }\end{array}$} \\
\hline Below barrier & $14.8 \pm 1.8$ & $11.7 \pm 1.7$ & \\
\hline On or above barrier & $0.1 \pm 0.1$ & $1.2 \pm 0.3$ & \\
\hline$\%$ Barrier efficiency ${ }^{a}$ & $99.2 \pm 0.7$ & $83.3 \pm 3.6$ & $20.3^{b}$ \\
\hline \multicolumn{4}{|l|}{$\begin{array}{l}\text { Mean } \pm \text { SE hide beetle } \\
\text { larvae collected/ } \\
\text { cardboard trap: }\end{array}$} \\
\hline Below barriers & $38.2 \pm 6.1$ & $23.8 \pm 9.7$ & \\
\hline Above barriers & $0.2 \pm 0.1$ & $3.1 \pm 0.5$ & \\
\hline \% Barrier efficiency & $99.5 \pm 0.1$ & $88.5 \pm 1.8$ & $12.5^{b}$ \\
\hline \multicolumn{4}{|l|}{$\begin{array}{l}\text { Mean } \pm \text { SE lesser } \\
\text { mealworm larvae } \\
\text { collected/cardboard } \\
\text { trap: }\end{array}$} \\
\hline Below barriers & $1.8 \pm 1.1$ & $0.8 \pm 0.3$ & \\
\hline Above barriers & $0.0 \pm 0.0$ & $0.1 \pm 0.1$ & \\
\hline$\%$ Barrier efficiency & $100.0 \pm 0.0$ & $88.8 \pm 8.2$ & $2.6 \mathrm{NS}$ \\
\hline
\end{tabular}

$n=2 \mathrm{wk}$ of observations of 21 posts per treatment per week for visual counts, 10 traps per treatment per week for trap counts.

${ }^{a}$ Number of beetle larvae observed below barrier/total larvae observed.

${ }^{b} P<0.01 ; \mathrm{NS}, P>0.05$.

Results of direct observations of hide beetle larval activity from September to November indicated that the barriers were $>94 \%$ effective against these larvae until 23 October (Table 3). Barrier effectiveness decreased somewhat in subsequent weeks, with a decrease in barrier efficiency from 97.3 to $87.9 \%$ occurring when accumulated fly spotting exceeded $31 \mathrm{fly}$ spots per square centimeter. Even in the presence of this high fly activity, barriers remained 79-88\% effective through 24 November (Table 3).

Further evidence for the effect of fly spot deposition on barrier efficiency is provided in Table 4, where barriers were categorized individually according to the severity of local fly activity. Although all posts in the facility were examined, those posts where no larvae were observed were excluded from the analysis, resulting in total postnumbers of $<102$ on both sampling dates. Barriers with little spotting $(<20 \%$ of the plastic covered) remained $99-100 \%$ effective, whereas the efficiency of heavily spotted barriers (>80\% covered) declined to $40-56 \%$ (Table 4 ).

Removal of fly spots with water on 3 December restored the efficiency of the barriers to $>99 \%$ for hide beetle larvae compared with $83 \%$ efficiency for unwashed posts, as determined by visual counts (Table 5). Similar results were observed with hide beetle when larval activity was measured by cardboard traps. No significant washing treatment effect was observed with lesser mealworm larvae, but counts of this beetle were very low in both treatment groups (Table 5).

Collections of beetles from the "maze" collecting devices at the end of the house varied considerably from week to week, but these devices captured an average of $2,488 \pm 500.6$ hide beetle larvae per week (Table 6). Small numbers of lesser mealworm larvae were collected (mean, 73.6 \pm 45.2 ), as were adults of the predaceous histerid beetle Carcinops pumilio (Erichson) (mean, $283.9 \pm 68.4$ ).

\section{Discussion}

Little is known about the factors that determine the relative abundance of lesser mealworm and hide beetle populations in poultry houses. The two species often occur sympatrically and have similar developmental rates (Cloud and Collison 1986, Rueda and Axtell 1996). Although hide beetle populations are generally favored by high-protein food sources (Cloud and Collison 1986), their populations in the field are erratic and difficult to predict (Stafford et al. 1888). In caged-layer houses, hide beetle populations sometimes spread from foci near accumulations of broken eggs or dead birds into surrounding areas (C.J.G., unpublished observations). We were surprised to find high populations of hide beetles in a pullet house because there were no chicken eggs and few dead birds in the manure pit. Indeed, hide beetles

Table 6. Collections of litter beetles in collecting traps placed at ends of concrete walls in a pullet house treated with a horizontal strip of a polyethylene terepthalate plastic and caulk barrier

\begin{tabular}{|c|c|c|c|c|c|c|}
\hline \multirow{2}{*}{ Date } & \multirow{2}{*}{$\begin{array}{c}\text { Trap } \\
\text { no. }\end{array}$} & \multicolumn{2}{|c|}{ Hide beetle } & \multicolumn{2}{|c|}{ Lesser mealworm } & \multirow{2}{*}{$\begin{array}{c}\text { Carcinops } \\
\text { pumilio } \\
\text { Adults }\end{array}$} \\
\hline & & Larvae & Adults & Larvae & Adults & \\
\hline \multirow[t]{2}{*}{16 Oct } & 1 & 4,500 & 72 & 21 & 185 & 71 \\
\hline & 2 & 6,372 & 100 & 30 & 227 & 218 \\
\hline \multirow[t]{2}{*}{23 Oct } & 1 & 2,067 & 46 & 0 & 134 & 263 \\
\hline & 2 & 3,756 & 38 & 19 & 172 & 443 \\
\hline \multirow[t]{2}{*}{29 Oct } & 1 & 702 & 107 & 0 & 117 & 336 \\
\hline & 2 & 4,326 & 144 & 0 & 82 & 1,030 \\
\hline \multirow[t]{2}{*}{5 Nov } & 1 & 31 & 3 & 0 & 1 & 2 \\
\hline & 2 & 2,290 & 3 & 21 & 3 & 207 \\
\hline \multirow[t]{2}{*}{12 Nov } & 1 & 836 & 1 & 8 & 1 & 128 \\
\hline & 2 & 1,408 & 3 & 12 & 7 & 200 \\
\hline \multirow[t]{2}{*}{19 Nov } & 1 & 418 & 1 & 16 & 15 & 45 \\
\hline & 2 & 2,030 & 0 & 21 & 32 & 204 \\
\hline \multirow[t]{2}{*}{24 Nov } & 1 & 2,400 & 0 & 367 & 428 & 369 \\
\hline & 2 & 3,340 & 0 & 515 & 555 & 458 \\
\hline Mean $\pm \mathrm{SE}$ & & $2,488.2 \pm 500.6$ & $37.0 \pm 13.2$ & $73.6 \pm 42.4$ & $139.9 \pm 45.2$ & $283.9 \pm 68.4$ \\
\hline
\end{tabular}


appear to be an increasing problem in poultry houses in many areas (Geden et al. 1999a). The reasons for this increase in prevalence are unclear, but may be due to a combination of improved ventilation in many facilities (Geden et al. 1999b) and adaptation by the beetles to the poultry house environment.

Mechanical barriers have long been used as a method for excluding lepidopterans from reaching tree canopies (Blumenthal and Hoover 1986, Forbush and Fernald 1896), for excluding pests from agricultural crops (Jansson et al. 1987), and for excluding beneficial insects and competitors in ecological studies (Miller 1985, Holopainen and Varis 1986). Our results demonstrate that lesser mealworm and hide beetle larvae can be prevented from climbing support posts and walls in poultry houses by the use of a polyethylene terepthalate plastic barrier. The results also indicate that the barriers were tolerant of field conditions and required no maintenance beyond the removal of fly spots following severe fly outbreaks. Fly spot removal was easily accomplished in $2 \mathrm{~h}$ by the use of water and sponges. Although other materials such as polyvinyl chloride films, acrylic sheets, or metal could be used for this purpose, polyethylene terepthalate plastic is inexpensive, easily shaped and cut, chemically inert in the poultry house habitat, and can be attached to various surfaces with common latex or silicone caulk adhesives. In our study, the greatest risk to the barriers was during house cleanouts, when sections of the horizontal wall strip were sometimes damaged by manure removal equipment.

Although the design features of the test site made it impractical to monitor larvae above and below the wall-mounted barrier, the barrier plus "maze" collecting device provided a simple method for the collection and disposal of thousands of litter beetle larvae that may otherwise have resulted in damage to the facility. On one sampling date alone (16 October), these devices collected nearly 11,000 hide beetle larvae, indicating that building walls are a major route of movement for dispersing larvae of this species. Any effort to prevent damage by these pests must address larval emigration via walls as well as posts.

We occasionally observed hide beetle larvae boring into the wood in the area immediately below the postmounted barriers. Such damage could be mitigated by the use of small quantities of toxicants or repellents such as neem oil extract on the wood beneath the lower barrier margin (Ascher 1993). Additional research is needed to identify litter beetle repellents, attractants and semiochemicals that could be deployed in concert with mechanical barriers to manage the behavior of these insects (Tseng et al. 1971, Yinon et al. 1971, Rakowski and Cymborowski 1986).

\section{Acknowledgments}

We thank B. Talton, S. Wren, H. Brown, and J. Hogsette for their assistance during this study.

\section{References Cited}

Ascher, K.R.S. 1993. Nonconventional insecticidal effects pesticides available from the neem tree, Azadirachta indica. Arch. Insect Biochem. Physiol. 22: 433-449.

Avancini, R.M.P., and M. T. Ueta. 1990. Manure breeding insects (Diptera and Coleoptera) responsible for cestoidosis in caged layer hens. J. Appl. Entomol. 110: 307-312.

Axtell, R. C., and J. J. Arends. 1990. Ecology and management of arthropod pests of poultry. Annu. Rev. Entomol. 35: 101-126.

Blumenthal, E. M., and C. R. Hoover. 1986. Gypsy moth (Lepidoptera: Lymantridae) population control using mechanical barriers and contact insecticides applied to tree stems. J. Econ. Entomol. 79: 1394-1396.

Cloud, J. A., and C. H. Collison. 1985. Laboratory evaluation of insecticides for control of adult and larval hide beetles, Dermestes maculatus DeGeer, from poultry houses. J. Agric. Entomol. 2: 297-308.

Cloud, J. A., and C. H. Collison. 1986. Comparison of various poultry house litter components for hide beetle (Dermestes maculatus DeGeer) larval development in the laboratory. Poultry Sci. 65: 1911-1914.

Despins, J. L., E. C. Turner, Jr., and D. G. Pfeiffer. 1991. Evaluation of methods to protect poultry house insulation from infestations by lesser mealworm (Coleoptera: Tenebrionidae). J. Agric. Entomol. 8: 209-217.

Despins, J. L., R. C. Axtell, D. A. Rives, J. S. Guy, and M. D. Ficken. 1994. Transmission of enteric pathogens of turkeys by darkling beetle larva (Alphitobius diaperinus). J. Appl. Poultry Res 3: 1-5.

Forbush, E. H., and C. H. Fernald. 1896. The gypsy moth, Porthetria dispar (Linn.): a report of the work of destroying the insect in the commonwealth of Massachusetts, together with an account of its history and its habits both in Massachusetts and in Europe. Boston, Wright, and Potter, Boston.

Geden, C. J., and R. C. Axtell. 1987. Factors affecting climbing and tunneling behavior of the lesser mealworm, $\mathrm{Al}$ phitobius diaperinus (Coleoptera: Tenebrionidae). J. Econ. Entomol. 80: 1197-1204.

Geden, C. J., J. J. Arends, and R. C. Axtell. 1987a. Field trials of Steinernema feltiae (Nematoda: Steinernematidae) for control of Alphitobius diaperinus (Coleoptera: Tenebrionidae) in commercial broiler and turkey houses. J. Econ. Entomol. 80: 136-141.

Geden, C. J., T. D. Edwards, J. J. Arends, and R. C. Axtell. 1987b. Efficacies of mixtures of insecticides and disinfectants. Poultry Sci. 66: 659-665.

Geden, C. J., J. J. Arends, D. A. Rutz, and D. C. Steinkaus. 1998. Laboratory evaluation of Beauveria bassiana (Monilales: Moniliaceae) against the lesser mealworm, Alphitobius diaperinus (Coleoptera: Tenebrionidae), in poultry litter, soil and a pupal trap. Biol. Control 13: 71-77.

Geden, C. J., J. J. Arends, R. C. Axtell, D. R. Barnard, D. M. Gaydon, L. A. Hickle, J. A. Hogsette, B. A. Mullens, M. P. Nolan, Jr., M. P. Nolan III, J. J. Petersen, and D. C. Sheppard. 1999a. Res. and extension needs for poultry IPM, in: Hogsette, J. A. and C. J. Geden (eds.), Research and extension needs for integrated management programs for livestock and poultry (http://www.ars.grin. gov/ars/SoAtlantic/Gainesville/cm fly/Lincoln.html).

Geden, C. J., J. A. Hogsette, and R. D. Jacobs. 1999b. Effect of airflow on house fly (Diptera: Muscidae) distribution in poultry houses. J. Econ. Entomol. 92: 416-420.

Holopainen, J. K., and A. L. Varis. 1986. Effects of a mechanical barrier and formalin preservative on pitfall catches of carabid beetles (Coleoptera: Carabidae) in arable fields. J. Appl. Entomol. 102: 440-445. 
Ichinose, T., S. Shibazaki, and M. Ohta. 1980. Studies on the biology and mode of infestation of the tenebrionid beetle Alphitobius diaperinus (Panzer) harmful to broilerchicken houses. Jpn. J. Appl. Zool. 34: 417-421.

Jansson, R. K., H. H. Bryan, and K. A. Sorenson. 1987. Within-vine distribution and damage of sweetpotato weevil, Cylas formicarius elegantus (Coleoptera: Curculionidae), on four cultivars of sweet potato in southern Florida. Fla. Entomol. 70: 523-526.

McAllister, J. C., C. D. Steelman, and J. K. Skeeles. 1994. Reservoir competence of Alphitobius diaperinus (Coleoptera: Tenebrionidae) for Salmonella typhimurium (Eubacteriales: Enterobacteriaceae). J. Med. Entomol. 31:369-372.

McAllister, J. C., C. D. Steelman, J. K. Skeeles, L. A. Newberry, and E. E. Gbur. 1996. Reservoir competence of Alphitobius diaperinus (Coleoptera: Tenebrionidae) for Escherichia coli (Eubacteriales: Enterobacteriaceae). J. Med. Entomol. 33: 983-987.

Miller, M. C. 1985. The effect of Monochamus titillator (F.) (Col., Cerambycidae) foraging on the emergence of Ips calligraphus (Germ.) (Col., Scolytidae) insect associates. Z. Angew. Entomol. 100: 189-197.

Rakowski, G., and B. Cymborowski. 1986. Some environmental and physiological factors influencing the response of the hide beetle, Dermestes maculatus, to aggregation pheromone. Int. J. Invertebr. Reprod. Dev. 9: 35-41.

Riley, D. G., G. K. Douce, and R. M. McPherson. 1997. Summary of losses from insect damage and costs of control in Georgia in 1996. Georgia Agricultural Experiment Station Special Publication No. 91. University of Georgia, Atlanta.

Rueda, L. M., and R. C. Axtell. 1996. Temperature-dependent development and survival of the lesser mealworm Alphitobius diaperinus. Med. Vet. Entomol. 10: 80-86.
SAS Institute. 1987. SAS users guide: statistics. SAS Institute, Cary, NC.

Stafford, K. C., III, C. H. Collison, J. G. Burg, and J. A. Cloud. 1988. Distribution and monitoring lesser mealworms, hide beetles, and other fauna in high-rise, caged-layer poultry houses. J. Agric. Entomol. 5:89 101.

Steinkraus, D. C., and E. A. Cross. 1993. Description and life history of Acarophenax mahunkai n. sp. (Acari, Tarsonemina: Acarophenacidae), an egg parasite of the lesser mealworm (Coleoptera: Tenebrionidae). Ann. Entomol. Soc. Am. 86: 239-249.

Steinkraus, D. C., C. J. Geden, and D. A. Rutz. 1991. Susceptibility of lesser mealworm (Coleoptera: Tenebrionidae) to Beauveria bassiana: effects of host stage, formulation, substrate and host passage. J. Med. Entomol. 28: 314-321.

Steinkraus, D. C., W. A. Brooks, G. J. Geden, and D. A. Rutz. 1992. Discovery of Farinocystis tribolii and eugregarine in the lesser mealworm, Alphitobius diaperinus. J. Invertebr. Pathol. 59: 203-205.

Tseng, Y.-C.L., J. A. Davidson, and R. E. Menzer. 1971. Morphology and chemistry of the odoriferous gland of the lesser mealworm, Alphitobius diaprinus (Coleoptera: Tenebrionidae). Ann. Entomol. Soc. Am. 64: 425-430.

Turner, E. C., Jr. 1986. Structural and litter pests. Poultry Sci. 65: 644-648.

Vaughan, J. A., E. C. Turner, Jr., and P. L. Ruszler. 1984. Infestation and damage of poultry house insulation by the lesser mealworm, Alphitobius diaprinus (Panzer). Poultry Sci. 63: 1094-1100.

Yinon, U., A. Shulov, and R. Ikan. 1971. The olfactory responses of granary beetles towards natural and synthetic fatty acid esters. J. Insect Physiol. 17: 1037-1049. 